\title{
Thomistic philosophical anthropology: a critique of freud's psychoanalysis
}

\begin{abstract}
This study through a philosophical analysis and hermeneutic argues that following the spiritual nature of some non-easily deniable realities like God and human soul, there cannot be an effective study of them without the connection of faith and reason and without the recognition of metaphysics. This paper, contending that the essence and being of a human person is closely connected to these two metaphysical realities, avers that any study carried out on and about the human person with a severance of these two strongholds to human being will be deficient. It $\mathrm{x}$-rays and defends Thomistic conception of a human person as more proper, accurate and faultless and uses it to critically assess the psychological theory of psychoanalysis propounded by Sigmund Freud which it finds defective.
\end{abstract}

Volume I Issue 3 - 2017

\author{
Matthew Ikechukwu Nwafor \\ Godfrey Okoye University, Nigeria
}

Correspondence: Matthew Ikechukwu Nwafor, Godfrey Okoye University, Nigeria, Email mattiyke2@gmail.com

Received: November 06, 2017 | Published: November 15, 2017

\section{Preamble}

In the Faculties of Arts and Humanities of universities, the two departments that have always found a "natural" connection which often has been proven hard to place apart from each other are the departments of religion and philosophy. Where there is a department of theology, the latest also finds itself a sister discipline to these other two. The reason is that all the three sciences usually come across in different ways in its separate field, the quest and search for the knowledge of the Ultimate Being or Reality. Though theology specifically emphasizes the use of faith as its important instrument for this study, it recognizes without any contradiction that its tool (faith) is never against the tools of the other two related disciplines-philosophy and its use of pure reason; and religion with its use of reason and other available approaches. Faith itself is never irrational or non-rational. It "presupposes natural knowledge." What is spectacularly different about it is that it involves but also goes beyond reason and rationality. This is not problematic as some scholars erroneously view it. If the subject matter of theology which philosophy and religion also study is viewed as transcendental and absolute by many scholars, it follows that the best valid and coherent way to establish its existence since it cannot be logically denied without running into vicious circle or infinite regress to the abhorrence and detest of the nature of reason itself, is the measure taken by faith. One only accepts what is beyond oneself. A non-absolute limited being cannot comprehend in totality the nature of an absolute non-limited being.

\section{Introduction}

A French word for rebirth "implying a rediscovery of rational civilization" against the judged superstitious primitivity of the medieval era. Its true name is Renaissance-the 14th century phenomenon that marked the beginning of the crisis in the marriage between faith and reason which got to its zenith in the Age of Enlightenment. Through its claim of humanism, it succeeded in bringing the final divorce to the natural union between faith and reason. With the severance of the union of these spouses (faith and reason) through which each of them truly realizes itself, faith arrogantly became full of itself manifesting in fanaticism and fideism. Reason lost its divine connection and went materialistic and merely natural- abhorring everything that is supernatural and spiritual.
By the 18th century Age of Enlightenment, even the fideism of faith was highly questioned and gradually faith itself was dethroned and its connection to any intellectual pursuit viewed as a taboo. Philosophy, that quest for wisdom and truth was also hit by this intellectual anomaly. Philosophy lost its metaphysical-ontological centrality. The effect of this situation like the biblical original sin, was spread to all its branches including psychology.

It was bewildering to every sane mind how an enterprise that has its etymological meaning as the study of the mind or soul which, considering the nature of its subject matter, would have "commonsensically" or ordinarily taken metaphysics as its foundation detested it and despised its transcendental dimension. Instead, human soul was analyzed without reference to the Ultimate Supreme Spirit where it originated from. This was typified in the psychoanalysis of Freud, Adler and Jung. The same half-truth about human psychology was found in the later psychological theories like the behaviorism of Pavlov, Watson, Skinner and their colleagues who studied human behavior as exclusively determined without reference to a rational soul. When eventually the soul seemed to have been recognized in the claim of the humanistic psychologists like Maslow and Rogers, it was taken in error to the other extreme as the absolute good that only seeks to actualize itself.

With the separation of psychology from philosophy, psychology had three foundational stages before coming to what we know about it in the contemporary time. These three stages are:

1. Psychoanalysis championed first by Sigmund Freud, Alfred W. Adler and Carl Gustav Jung.

2. Behaviorism taught and defended by Ivan Petrovitch Pavlov, John B. Watson, Burrhus Frederic Skinner etc.

3. Humanistic Psychology propounded by Abraham Maslow, Carl Rogers, Rollo May, James Bugental, Erich Fromm and so on.

Freud has the credit as the trail brazier or pathfinder of all the other stages. Those who belong to the same school do not always have exactly the same notion in the details of their view but have essential characteristics that qualify them as members of that school. For instance, Jung differed with Freud in some of his views but maintained that psychoanalysis is the best approach in psychology. 
Each stage saw the preceding stage as deficient and worked to update and upgrade it. However, none of the schools had an effective study of the human psychology because all of them have a deficient conception of a human person. This is why we shall examine the Thomistic anthropology in relation to these psychologists. We shall however limit our evaluation on the distortive anthropological implications that emerge from the doctrines of Sigmund Freud who was the trendsetter for the latter psychologists and their own propositions.

\section{The thomistic philosophical anthropology}

Before we examine the philosophical anthropology of Thomas Aquinas - a kingpin of Scholasticism, it is necessary to clarify an issue that is often mistaken. One thing that is not easy to deny is the close link between the Scholastics and their philosophies to Christian beliefs. This is why some contemporary philosophers argue that their analyses and interpretations are not qualified to be called philosophy. Whether this should be taken as true depends on the answer that will be given to the following questions: Can one philosophize in a vacuum? What are the ingredients for philosophizing? If being constitutes the core interest of philosophy and everything that is, is being, is it possible then to limit the subject matter of philosophy to some particular things? If the greatest tool for philosophizing is pure reason, did the Scholastics not apply this in their own enterprise? I would think that the major difference between the Scholastics and those other modern and postmodern philosophers is the relationship of truth to the mind and the issue of telos. While the Scholastics hold that truth is not dependent on the mind's discretion and conclusion, their successor's subject truth to the interpretation of the mind and what it establishes it to be. Because of this variation, the Scholastics have some ends/goals (truth) already in mind which they only wish to unravel and comprehend with pure reason. However, for the opponents of the scholastics, these ends/ goals are obstacles to achieving an unbiased truth. For them, truth is not outside the detect of the mind hence no end exists before the mind defines it. The explanation of Tauber ${ }^{1}$ might help to buttress what we mean: Modern science in many ways exemplifies the Age of Reason; specifically, I am referring to its program of truth-seeking. Somewhat chastened by the postmodern critique of any final Truth, I still believe we make an important distinction between an understanding of reason that serves a predetermined goal (for instance one defined by religious faith that is constrained a priori by presuppositions deemed immune in advance to questioning), as opposed to the use of enlightened reason that is open-ended. Inquiry in this latter formulation has no telos other than the inquiry itself. In this sense, scientific knowledge is neutral; the process of study is putatively immune to bias and prejudice (at least in its theoretical prime state); fallibilism is assumed; objectivity is sought.

It seems more correct to understand Tauber's idea of immunity to questioning as non-distortion of reality and truth. Another fact is that the objectivity sought by science is the type that ironically hinges on individual opinion and view. The nagging problem to this is an endless speculation where nothing is established as truth. Truth rather depends on what each individual makes it or makes of it.

The Thomistic anthropology is centered on the idea of person which was the word coined by Christian scholars in their struggle to explain the mystery of the Trinity. It also marked the line of demarcation between Christianity and other preceding culture to it. Before this radical change in the Greek word for person known as prosopon which literally means disguising or mask, there was no word to express the concept of a person as we have today. This is owing to the denial of absolute value to human being by Greek culture which places such absolute value on rank, wealth and race. Therefore, considering the historical background to the word person, there is no gainsaying the fact that no true and wholistic meaning of the concept can come outside Christian-related view since it originated from it. With the formulation of the word person, Christian scholars popularly known as the Scholastics now have proper definition of a human being.

Thomas Aquinas gave to the scholarly world a philosophical anthropology that has defied total abhorrence and neglect because of the undeniable and unavoidable truths that it contains. Although his explanation is rooted in the uncontradictory but complementary definitions of person by Augustine and Boethius, his idea remains very remarkable because of its clarity and rationality.

Augustine began his excursus into the formulation of the concept of a person when he discovered that the two common and recurring words around the meaning of the Trinity: essence and substance could not define their individuality Istvan. ${ }^{2}$ Notes that "the reason why Trinity is not three substances but three persons is that earlier Augustine has [had] used the term of substance in a meaning of essence and he wanted to avoid the confusion of terms. Person in this meaning is such entity which can be separated by its own quality from other beings, but it does not have its own essential existence" Mondin. ${ }^{3}$ Reiterated a similar fact when he explained that Augustine wanted "to find a term that could be applied distinctly to the Father, Son, and Spirit -without falling, on one hand, into the danger of making of them three divinities, and, on the other hand, into the danger of dissolving their individuality". The word that could make this distinction is hypostasis which is the same as Latin persona. So, for Augustine, the idea of a person is related to individuality. With the coinage of the word "person," Augustine sets the motion for other scholars like Boethius who built and expanded the meaning the meaning of the concept.

According to Paolo Sommaggio, ${ }^{4}$ "in order to understand what was meant by the word, he (Boethius) analyzed the concept of nature, which in fact has a broader meaning than person and to some extent is its genus proximus." Paolo adds that since for Boethius, "nature is the specific difference that gives form to each thing", it follows that a person must have a nature. But looking at this, the following sequence or chains of questions will arise: Would this nature be substance or accident? If it is substance as Boethius holds, would it be incorporeal or corporeal; living or non-living, particular or universal? If it is living, is it the rational living substance or the non-rational living substance? Paolo maintains that it is the synthesis of this that led to Boethius' definition of a person as "the individual substance of a rational nature." Then, commenting on this definition, Mondin points that Boethius was the one who added that important feature of a man, that is, rationality. According to him, Boethius saw that "not even the union of individuality, nature, and substance make a person; these elements even belong to a stone or a cat, which are not persons" (p. 246).

However, the greatness of Aquinas lies on his genius discovery of one more lacuna in the definition of a person by Boethius. For Aquinas, a person even though he possesses individuality, nature and substance lacks subsistens which confers actuality to the substance of its being. Without the act of being, a person will not have that ontological wholeness that makes him a concrete being. Quoting Aquinas' Summa Theologia, Mondin states that "the actus essendi gives to the person the property of incommunicability." (p. 248). This 
is what makes a person to become "ontologically closed" that is, to become complete in itself. Expatiating this, he disclosed the three connected ways enumerated by Aquinas in which a person enjoys incommunicability: "First of all, the individual who is a person cannot communicate with other things as a part, being a complete totality; then he cannot communicate as the universal communicates with the individuals, in that the person is something assumable, because that which is assumable passes in the personality of the assumer and no longer has its own personality..." The summary point is that with the feature of incommunicability, a person becomes not just nature or essence because "the concept of a person allows that what is being spoken of is something distinct, subsistent, and inclusive of all that is in the thing; instead, the concept of nature only embraces the essential elements." (p. 248).

All of these explanations and even of the relationality that would be developed about human person are possible only when one views a human person as an embodied spirit, that is, as a component of body and soul with an intrinsic relationship between them. Aquinas did an expansive analysis of the nature of these components and how the relationship between them is possible. The nature of the body as corporeal raises no controversy but that of the soul does. For Aquinas, the soul is a spiritual substance. It is the form of the body Torchia, states that "for Aquinas, the soul is a substantial reality, as the form of a certain kind of body." It is the act of the body conjoined by it "in an inextricable union comprising one substantial reality." (p. 131). Thus, the relationship between the soul and the body or the mode in which the soul is united to the body is not like a "motor" as Plato taught. Those who agree with Plato's view on the unity of the soul to the body as merely like the unity between a vehicle and what it moves; often end up in the error of taking the soul to be body. According to Pegis, ${ }^{6}$ the vanguards of this position usually present their arguments thus: "...between the mover and the moved there must be a contact. But contact is only between bodies. Since, therefore, the soul moves the body, it seems that the soul must be a body." Against this view however is Aquinas' response which Pegis also expresses viz: "There are two kinds of contact, that of quantity, and that of power. By the former a body can be touched only by a body; by the latter a body can be touched by an incorporeal reality, which moves that body" (p.684).

Even though Thomistic anthropology centers greatly on the soul, yet, he maintains that the soul is not body and it alone is not a human person. The evidence of this is clear in the following explanation:

Soul and body require each other: the soul depends on the body as its instrumentality in the world, and the body depends on the soul as its principle of life and activity. As the form of the body, the soul must be simultaneously present to the whole body and to each of its parts. As the intellectual principle, the rational human soul raises all of the activities of human life (including those we share in common with plants and animals) to a higher plane Torchia. ${ }^{5}$

From this synthesis of Aquinas, Mondin ${ }^{3}$ comes up with this succinct but wholistic view on the meaning of a person. According to him, a person "can be defined as a subsistent gifted with self-consciousness, communication, and self-transcendence." He very importantly adds: By virtue of subsistence he is distinct from all others; through selfconsciousness he recognizes himself as unique and unrepeatable but at the same time free, social and perfectible; through communication he enters into rapport with others - in a rapport of love, friendship, and sympathy, but also in a rapport of aversion, hate and hostility and through self-transcendence he is called to surpass all the confines with which space and time seek to block his ascension, as he attempts to penetrate the realm of the absolute and eternal.

The deduction from all the attributes of a person enumerated above is that he must have originated from a Pure Absolute Spirit thus the Christian idea that a person is created by God and in God's image. According to Clark, ${ }^{7}$ Aquinas affirmed this truth when he said that "all things have being insofar as they are like God, who is selfsubsistent being; for only by participation are they beings." Again, the limitations of human persons some of which manifest in aversions and hatred indicate that he has a weak or distorted nature. This resonates with the Christian idea of the effect of the original sin. What about his human abilities and positive qualities? His ability such as selftranscendence indicates that his distorted nature is endowed with an external force that aids it which is what Christian scholars including Aquinas called grace. Thus, human person was also redeemed from his fallenness.

\section{Sigmund schlomo freud}

Sigmund Freud was born on May 6, 1856 in an Austrian town of Freiberg by Galician Jewish parents. He was primarily a neurologist and got his degree in medicine in 1881 . They moved to Austria when he was four where he worked most of his life. In 1938, he left Austria to escape from the Nazis and he died in Hampstead London in 1939 at the age of eighty-three.

It is not uncommon to discover that most of the great people in history especially those who formulated theories with revolutionary ideas were deeply influenced by their life experience, their family background, and the philosophy and worldview of their age. Friedrich Nietzsche was one, Emmanuel Kant was one, Nicolaus Copernicus was one and others. The same is found in the case of Freud. We can explain the influences to Freud's theory under three categories:

\section{Family experience}

Freud experience in his family as he was growing up contributed greatly to his theory of Oedipus Complex which he expounded in his masterpiece The Interpretation of Dreams. He suffered from emotional crisis from his father's death, his relationship with his half-brother and his mother. He explained that he used to be deep in fantasies when he was growing up.

\section{Scientific climate of his time}

He was influenced by Darwin's doctrine of evolution published in the Origin of Species. In the doctrine of evolution, Darwin changed the popular view held about man before him. Instead of the view that man has a difference of essence from animals, Darwin said it was only a difference of degree. Thus, man becomes essential part of natural order equal to animals with difference not of his rational soul but only of his complex structure. This view opened a way for man to be made a subject for scientific investigation and explanation.

\section{Field of physics and modern science}

Discoveries in the fields of thermodynamics, electromagnetism and nuclear physics influenced the worldview of the contemporary of Freud. The principle of conservation of energy was applied in the understanding of human mind such that for Freud, there is such a thing as psychic energy whereby human personality is also an energy system which psychology investigates for modification, transmission and conversions. This becomes the foundation for his psychoanalytic theory. 


\section{Freud's theory of psychoanalysis}

Freud has a number of theories that led him to the formulation of psychoanalysis as a therapy. These theories can be grouped under the following sub-themes: The theory of the Unconscious Mind: Before Freud, the unconscious mind was never regarded as very necessary in defining a human person. From Freud, this revolutionary idea crept into human knowledge. The mind or the soul was viewed as free in its nature and was seen as central in the influence of human action. This was changed by Freud who preferred to study man via his unconscious self instead of his rational conscious self. For many though, it was not a surprise since Freud had already viewed man as a psychic energy totally natural with no spiritual dimension in him. By this notion, man is taken to be completely determined with no freewill. No human behavior could therefore be viewed as free or be expressed by choice because it is always determined by hidden causes in the person's mind. "An 'unconscious' mental process or event for Freud is not one which merely happens to be out of consciousness at a given time, but is rather one which cannot, except through protracted psychoanalysis, be brought to the forefront of consciousness. The postulation of such unconscious mental states entails, of course, that the mind is not, and cannot be, either identified with consciousness, or an object of consciousness."

Instead of reason which prompts the actions of the conscious mind, Freud maintains that it is the instincts or drives which motivate the unconscious mind. According to him, these drives or instincts are many but he chose to reduce them into two: Eros and Thanatos. He called Eros the life instinct and Thanatos the death instinct. Eros covers the instinct for self-preservation while Thanatos covers the instinct for aggression, self-determination and cruelty. By this, Freud made sexuality central to understanding everything about human life, human actions and human behavior. In children, there is infantile sexuality and in adults, there is the libido which is a strong determinant of adult life. For him, human life is geared towards pleasures of the body.

\section{The theory of infantile sexuality}

For Freud as it is for the psychanalysts after him, sexual instinct is the determinant of all human actions. The proof of this is reflected in the following enumerations which $\mathrm{Salter}^{8}$ described as "the principles that guide the psychanalyst in the treatment of EVERY man who comes into his office.” They include: (a). Sex underlies everything. (b). All dreams are fundamentally sexual (c). All psychological difficulties are manifestations of unexpressed sexuality (d). All boys want to have sexual intercourse with their mothers, [and]...to murder their fathers (e). The life of the child is fundamentally sexual (f). And in the words of Freud himself, "Generally speaking, every human being oscillates all through his life between heterosexual and homosexual feelings.

Freud 's idea would have faced criticism as a baseless assertion if he had not attempted the explanation of how possible this instinct could be exhibited in infants and babies. Freud's approach was believed to have been originated and animated by Breuer (his master), from whom he learned that "traumatic childhood events could have devastating negative effects upon the adult individual." Freud aped this idea stating that early childhood sexual experiences were "the crucial factors in the determination of the adult personality." It means that from birth, infants long for bodily pleasure (sexual pleasure).

Freud calls the first stage when infants manifest this bodily sexual pleasure as the Oral stage-the stage when they suck. He calls the second stage the Anal stage- when they defaecate. And the third stage he calls the Phallic stage - when the child develops interest in his sexual organ as a site of pleasure. At this third stage, he develops a big attraction for the parent of the opposite sex and a deep hatred for the parent of the same sex. This is what Freud described as the Oedipus complex. The condition in the phallic stage leads to the guilt in the child who now discovers that he can never supplant the stronger opposite sex parent. Subsequently too, fear sets into the child since he finds out that if he persists in the sexual attraction to the Mum, the Dad may harm him or even castrate him. Freud called this "Castration anxiety." The child now has no choice than to repress the two feelings of attractions to his mother and hatred for his father. In frustration for being left with no alternative, he turns in to cling to his parent of the same sex. This process takes place until the child grows to genital maturity when he diverts his pleasure drive to his genital. For Freud and other champions of his theory, the effect of this progression in the development of the child affects his adult life depending on whether they are resolved or not. For instance, many mental illnesses especially hysteria is traced back to the unresolved conflicts experienced at this stage. Some Freudian psychoanalysts trace the cause of homosexuality to the unresolved Oedipus complex when the child cringed to the parent of the same sex out of guilt, fear and frustration. Similarly, obsessive concern for washing and personal hygiene is sometimes traced to the unresolved conflict or repression from the anal stage.

\section{Neuroses and structure of the mind}

To be able to interpret the activities of the unconscious mind especially the neuroses that occur there which is central to his doctrine, Freud structured the mind into three. Unlike Plato who had similar tripartite structure as reason, spirit and appetite, Freud called them the id, the ego, and the superego. The id is the most important part of the mind in Freud's perspective because it is there that sexual drives or instincts reside and from where they long for satisfaction. The superego is where the conscience is situated. What constitute the conscience are the social norms that control the mind which are acquired first from parents and later from the society. The ego is the conscious self that is created by the tensions and interactions between the id and the superego. This conscious self (the ego) tries to reconcile the conflicting demand of these other two structures with the requirements of external reality. The struggle between the drives of the id and the inhibitive rules of the superego which the mind tries to prevent or to resolve sometimes expands, leading to neurosis. To explain the various situations in which the mind finds itself, Freud coined the following terms (and others) which he called the "Defense Mechanisms' of the mind. They include:

i. Repression: Pushing conflicts back to the unconscious.

ii. Sublimation: Channeling the sexual drives into socially acceptable achievements or goals like arts, poetry, writing etc.

iii. Fixation: Failure to progress beyond one of the developmental stages.

iv. Regression: A return to the behavior characteristics of one of the stages.

Of all these, Freud took particular interest in repression because that is what explains or stands as the core of his theory of psychoanalysis. 


\section{Psychoanalysis as a therapy}

Since in the perspective of Freud everything about human behavior stems from the unconscious mind, repression then becomes a very important defense mechanism for him because it agrees with his theory that every human action stems from his repressed feeling. This is the case both in a normal person and in a neurotic person since in both of them, the unresolved conflicts that are repressed into the unconscious play important roles. The only difference is that in a normal person, the repressed feelings are minimal while in a neurotic person, they are high and compulsive. But none between the two has control over his behavior. This is Freud's determinism. The task of psychoanalysis as therapy is therefore "to find the repressions which cause the neurotic symptoms by delving into the unconscious mind of the subject, and by bringing them to the forefront of consciousness, to allow the ego to confront them directly and thus to discharge them."

Psychoanalysis is both a theory and the clinical treatment to the neurosis or disorders that occur from an unresolved conflict in the mind during one's development. The aim is to re-establish a relationship between the three structures of the mind by resolving the unconscious repressed conflicts. Instead of the use of hypnosis as done by Breuer his master, Freud developed what he called the "talking cure" whereby the buried repressed conflicts in the deepest part of the unconscious mind is brought to the fore. The "patient" is made to relax and talk out his experience without consideration of the controls and rules of the superego. The psychoanalyst watches out for the patient's slips of tongue, free association and his response to some carefully selected questions which he analyses and through which he helps the patient to become conscious of the unresolved conflicts buried in the deep recesses of his unconscious mind. He guides the patient to confront these conflicts and engage with them directly.

The anthropological assumptions in freud theories and the critique of thomistic philosophical anthropology

There is a revealing truth in the question posed in the hymn of the one of the ancient Israelites' songs called the Psalm: "Foundation once destroyed, what can the just do?" No bad foundation makes a complete good house. One of the classical features of a human person is that unveiled in the definition of him as homo religiosus that is, as a religious being. The meaning of this goes beyond the question of belonging to one religious group/belief or the other to simply about the truth that a human person, owing to his nature is always intoned to the beyond, to the transcendence. This is of course the simplest meaning of religion. If in discussing about a human person, that inevitable, subcutaneous and natural influence of religion which is the connection with or the acknowledgement of the Supreme Ultimate Transcendence no matter what anyone calls it, is forced out of one's opinion, theory or ideology about him, violation and deficiency are bound to arise in the ensuing postulations. The psychoanalysis of Freud is a remarkable example to this. No wonder Zilboorg ${ }^{9}$ spoke of Freud's psychoanalysis in this manner: The atheistic surfacing of Freudian psychanalysis has neither insulated nor otherwise protected psychanalysis from the ever-present impact of those human aspects of psychotherapy which reveal the human personality as much more than a complex labyrinth of psychological mechanisms, and point to the transcending relationship between man and the unknown.

The error of Freud is first of all, a foundational error that tries to investigate or study a subject without connecting what constitutes its essence. The nature of a human person is incomplete without acknowledging its rational-spiritual soul. It is dangerous to study him (a human person) with no reference to this important part of his being.

Freud's psychological theory assumed a human person without a rational spiritual soul. He seemed oblivious of the fact that no human behavior can extricate itself from the inspiration or influence of the soul as the principle of life. If the soul which is of a spiritual nature has such an essential role in the being of a person, there is no doubt that it does likewise in his behavior. Consequently, no human behavior can be effectively studied without reference to the soul and without reference to the spiritual dimension of the human person which is rational and free and not exclusively determined. What Freud does not seem to know is that human person is not only his body. He is a psycho-somatic unit and there is a relationship between the two parts of him. The relationship between these two substances in a human person makes him a free and undetermined being no matter how much he is pulled by his instinct. There is something specifically human in the mind/soul which makes it rational, free and able to choose. Even though "reason may not control emotion directly all the time, it can do that indirectly by directing thoughts in another way."

Again, though Freud did well to acknowledge the presence of passion in a human person, he went extreme to present a human person as this passion as if human beings are mere animals and only tilt towards the abnormal. By this, Freud made a devastating reductionism of human nature. What defines a person cannot come from his irrational unconscious self. A person has not mere consciousness but a self-reflexive type of consciousness that helps him to think and reflect upon/about himself and his life. With this, the sexual drive in a person is not exactly the same with that of animals. Despite its great force in a person, sexual drive does not define or control the person. It is still under his control. Therefore, Eros in a human person is dignified because it ought to be ignited and guided by agape which is more consciously done. Again, every bodily pleasure in a person is not necessarily sexual. There are other social and psychological dimensions of a person that are important too. Freud's theory seems to have reincarnated in the "sexual revolution" in our contemporary society where some persons define their identity from their sexual nature or drive. The psychological theory of Freud can only make sense if it is called the psychology of only the Abnormal where the role of reason is just to excuse action and the will simply serves as an arena for unsettled conflicts. However, despite his "corrupt" view of a human person, Freud must be appreciated for his idea of sublimation which has become one of the best suggestions for some habits and addictions like masturbation and pornography.

We are very much aware that what makes a human act is the rationality that backs it up. This is also why morality is talked about in human actions even of those he shares with animals. This indubitable truth could not be defended by Freud whose psychanalysis has in the first place reduced a human person to mere instinct. Thus, man is conceived as same with other brutes. Freud did not hide this in the declaration he made in his letter to Pfister, his Christian friend who was also a pastor Wolman: ${ }^{10}$ Ethics is foreign to me, but you are a shepherd of souls. I do not bother my head much over the subject of good and evil; however, as a rule, I have discovered very little of "good" among men. From what I know of them, they are for the most part only rabble, whether they advocate one ethical system or another, or none at all... If it is necessary to speak of an ethic, I profess for my part a lofty ideal, from which all other ideals known to me, deviate, as a rule, in a most distressing manner. 
Ethics and morality which Freud conceived and represented as antagonistic gadflies were associated with his ego and superego. They were seen as external impositions which limit a person from living out his real being.

\section{Conclusion}

Truth is one and simple even though it has its aspects. The truth is that the right conception of a human person is the basic foundation for all true and effective psychotherapy. If the real and wholistic nature of a human person is not rightly considered in any psychological investigation or study, it becomes a destructive psychology that does more harm than good to the person seeking psychological help. The clear point is that this wholistic view of a human person is embedded in Thomistic philosophical anthropology. Therefore, even if a psychologist does not accept the Scholastic Christian position of Thomas Aquinas in all cases, he should not fail to accept the truth he taught about human person since it seems indubitable.

It does not seem feasible to undertake an effective or plausible study of a human person or human behavior which certainly arises from the personhood without due and proper reference to psychosomatic nature of the person adequately and palpably established in Thomistic anthropology. Freudian psychology demonstrated in his psychoanalysis inappropriately compartmentalized a person and studied his being and behavior from only a chosen perspective that does not consider the whole person but only his aspect. A part cannot equal a whole especially with reference to a rational being like human person who has a complex nature with many components that are more often than not, closely connected to one another in their functionality.

Another basic fact is that even though Freud's psychoanalysis has been grossly criticized as unscientific, psychology in general beyond only psychanalysis, cannot hope to be successful in its quest to understanding human mind and human person by describing itself as a pure natural and observable science without the supporting force of metaphysics, theology, religion and spirituality. Psychologists should be aware of the fact that their subject matter (human person and his behavior) has an essential component that defies the competence of natural science and goes beyond its jurisdiction of investigation.

\section{Acknowledgments}

None.

\section{Conflict of interest}

The author declares no conflict of interest.

\section{References}

1. Tauber Alfred I. "Science and Reason, Reason and Faith: A Kantian Perspective". In: Robert M Baird, Stuart E Rosenbaum, editors. Intelligent Design, Science or Religion? Critical Perspectives. USA: Prometheus Books; 2007.

2. Istvan Siklosi. "The Self-Awareness and the Formal Concept of Person by Augustine and Boethius". Délkelet Európa- South-East Europe International Relations Quarterly. 2013;4(1):1-8.

3. Mondin, Battista. Philosophical Anthropology. Italy: Urbaniana University Press; 2004.

4. Sommaggio, Paolo. "Boethius' Definition of Persona: A Fundamental Principle of Modern Legal Thought". Germany; 2005. p. 163-171.

5. Torchia, Joseph. Exploring Personhood: An Introduction to the Philosophy of Human Nature. USA: Rowman \& Littlefield Publishers Inc; 2008.

6. Pegis, Anton C. Basic Writings of Saint Thomas Aquinas. Indiana: Hackett Publishing Company; 1997.

7. Clark, Mary T. An Aquinas Reader: Selections from the Writings of Thomas Aquinas. USA: Doubleday and Company Inc; 1972.

8. Salter, Andrew. The Case Against Psychoanalysis. USA: The Citadel Press; 1965.

9. Zilboorg, Gregory. Freud and Religion: A Restatement of an Old Controversy. USA: The Newman Press; 1964.

10. Psychoanalysis and Catholicism. In: Wolman, Benjamin B, editors. USA: Gardener Press Inc. 